\title{
The 2005th Amman Message: Significant Reference for Nusantara Ulama to Enlarge the Existing Indonesian Plurality
}

\author{
H. Hadri Hasan and D.I Ansusa Putra \\ State Islamic University (UIN) Sulthan Thaha Saifuddin, Jambi, Indonesia \\ hadrihasan@uinjambi.ac.id
}

\begin{abstract}
The Amman Message (Arabic: رسالة عمان) signed by 500 Ulama from Moslem countries, both Shia and Sunni, on the 27th of Ramadan 1425 H or 9 November 2004 in Amman, Jordan. This declaration is a reaction to the widespread fragmentation and decentralization of Muslim identity. The Amman Message positioning Islamic valued vis-a-vis the dynamic modern world. The method used in this research was tracing the content of the book of Risalat Amman (Amman Message), especially to the Ulama consensus related to the topic of pluralism. As an Islamic scholars consensus from all over the world, the Amman Message discussed and decided some opinions on plurality. This article would parse the significance of this message and its contribution to the Indonesian Islamic scholars' perspective in perceiving the plurality existing in Indonesia modern world, within the Indonesian Islam and in context Indonesia cross religion discourse and dialogue intra-religion concept.
\end{abstract}

Keywords: Risalat Amman (Amman Message), Nusantara Ulama, Indonesian Plurality, and Islamic Interpretation.

\begin{abstract}
Abstrak
Risalat Amman atau Deklarasi Amman ditandatangani oleh 500 Ulama dari negaranegara Islam, baik Syiah maupun Sunni, pada tanggal 27 Ramadhan $1425 \mathrm{H}$ atau 9 November 2004 di Amman, Yordania. Deklarasi ini adalah reaksi terhadap fragmentasi dan desentralisasi identitas Muslim yang tersebar luas. Risalat Amman memposisikan nilai-nilai Islam vis a vis dunia modern yang dinamis. Metode yang digunakan dalam penelitian ini adalah penelusuran isi buku Risalat Amman, khususnya pada konsensus Ulama terkait dengan topik pluralisme. Sebagai konsensus ulama Islam dari seluruh dunia, Risalat Amman mendiskusikan dan memutuskan beberapa pendapat tentang pluralitas. Artikel ini akan menguraikan signifikansi risalah ini dan kontribusinya terhadap perspektif para ilmuwan Islam Indonesia dalam melihat pluralitas yang ada di dunia modern Indonesia, dalam Islam Indonesia dan dalam konteks Indonesia melintasi wacana agama dan dialog konsep intra-agama.
\end{abstract}

Kata Kunci: Risalat Amman, Ulama Nusantara, Keberagaman Indonesia, dan Interpretasi Islam. 
Millatī, Journal of Islamic Studies and Humanities, Vol. 3, No. 2, Des. 2018: 173-187

\section{Introduction}

In reality Islamist groups and movements are varied, diverse and frequently contradictory in positions concerning their identity visions and stances on internal and external affairs. Recently, we seem to be under the perception of a growing fragmentation and decentralization of religious authority in the Muslim world. No particular locale or community appear to be unaffected by the phenomenon. Internet sites, videos, "social" media, TV programs, ad-hoc establishments, itinerant carriers of religious messages, everyone and anyone now seems to be able to cast himself or herself as an authority-wielding Muslim. While increasing decentralization has been always a component of any religion, developments in the recent couple of centuries may have hastened the process considerably. ${ }^{1}$

Unfortunately, these days we are witnessing a tendency to strengthen fanaticism (ashabiyah) clustering, extremism (tatharruf), and even the unification (takfir) of one group in Muslims to other groups. Indeed, most sadly, the old issues that once divided the Muslims here are now being raised up to a level that is very dangerous to the unity of the ummah. Ulama play a central role in inspiring, encouraging, and providing examples for people to participate actively in the effort to realize unity. In order to achieve maximum results, ulama from various groups in Indonesia need to synergize to achieve the noble goal of Muslim unity in Indonesia. Therefore, for this purpose it was agreed upon the necessity of forming ideal understanding for the plurality and unity.

Muhammad Abduh, as a manifestation of his concern for the condition of today's backward Muslim, once said that what we call around us today is not really Islam. Because the glory and greatness of Islam is covered by the actions and behavior of Muslims itself "Al-Islam Mahjubun bi Al-Muslimin". ${ }^{2}$ That is by those who do not really understand the essence of religion and actually make damage on earth. These ugly matters - according to Al-Amir Syakieb Arsalan term- are seen as roots that lead to the decline of Muslims. Al-Amir Syakieb Arsalan firmly states that the cause of the decline of Muslims is not solely triggered by the rise of other civilizations outside of Islam, but rather because of the diseases that exist within the Muslim body itself. The split that occurs in the body of Muslims undermines the robustness and strength of the Ummah.

${ }^{1}$ Amir Syakib Arsalan, Limaza Ta'akhara Muslimun wa Taqaddama Ghairuhum, Lebanon: Dar Maktabah al-Hayat, 2011, 45-47

${ }^{2}$ Muhammad Abduh, Risalat al-Tauhid, Egypt: Majlis al-'Ala li Shu'un Islamiyah, 2009, 175 
This crisis raises the anxiety of intellectuals or so-called ulama's. The ulama's anxiety about fragmentation is very similar to al-Fawda (or anarchy). This phenomenon has received many reactions from scholars all over the world. For example, a 2005 declaration called Ris凹latAmIn or the Amman Message. This declaration is a reaction to the widespread fragmentation and decentralization of Muslim identity and the treatment of non-Muslims.

Normatively, the study of various verses of the Qur'an will lead us to understanding the realization of the unity of the ummah of Islam one religious error. What can be seen in Surah Al Anbiya verse 92 and Al Mukminun verse 52 , the issue of the unity of this ummah is the same as the command of worship and piety to Allah. Meanwhile, in the verse of Ali Imran verse 103, the command to unite (cling to the ropes of God) is directly connected with the prohibition to divide. On the other hand, the facts show that various efforts to solve the problems of the Muslim world have always been hit with divisions. The cases of Palestine, Iraq and Afghanistan can serve as an example. In the context of Indonesian-ness, in view of the fact that the ummah of Islam occupies the position of the majority in Indonesia, this issue of harmony between Muslim groups will be the determinant of the unity of the NKRI (Unitary State of the Republic of Indonesia). We cannot expect to create the unity of Indonesia as a great nation if among Muslims there are being split.

\section{Re-Interpreting Islam Through Risalat al-Amman}

In the development of the decentralization and fragmentation phenomenon in the Islamic community, Some organisms are referred to recenly muslim condution as 'Crisis of Authority', derived from Muslims' reaction to the construction of 'modernity' and to the West, with a mix of new modes, including vernacularism, Cultural print, new media, and more and more new opportunities and challenges, this crisis process has been going on for two centuries. This crisis raises the anxiety of intellectuals or so-called ulama's. The ulama's anxiety about fragmentation is very similar to al-Fawda (or anarchy). 
Millatī, Journal of Islamic Studies and Humanities, Vol. 3, No. 2, Des. 2018: 173-187

In this context, it seems that the "crisis" of the scholars of Islam ("ulam $\vec{a})^{3}$ has been given the most attention, particularly when the state constrains the scope of their functions and controls their juridical output. Intensifying appeals from the scholars, judges, imams, and leaders of official religious boards and organizations who are widely regarded as the guardians, transmitters and interpreters of religious knowledge, doctrine and law to regulate Islam (and, in essence, to reclaim their increasingly diminishing power) seem to fall on deaf ears. The 'ulamä's anxiety over the fragmentation of religious authority is particularly noticeable in their characterization of the trend in terms of fawd $\bar{a}$ - namely, chaos or anarchy. ${ }^{4}$ Ulama Attempts to counter this phenomenon around all the world to - what amounts, practically - the defiance of their authority serve to exemplify how potent this issue has become. ${ }^{5}$

All these fragmantation and desentralization happen because religion is part of globalization. It is inevitable that the mobilization of people also impacts on the mobilization of religion, belief, thought, culture and ideology. It is therefore impossible to deny the rapid development and changes caused by globalization. All that can be done is to strengthen faith in their respective religions and beliefs, making it an identity in interaction and dialogue. one of the attempts of dialogue that has been pursued For example, a $2005^{\text {th }}$ declaration called Risālat Amān or the Amman Message.

The Amman Message signed less than 500 scholars both Shia and Sunni. The Amman Message (رسالة عمان) began as a declaration released on the 27th of Ramadan $1425 \mathrm{H}$ coincides with the 9 November 2004 M by HM King Abdullah II bin Al-Hussein in Amman, Jordan. The Amman Message (رسالة عمان) stems from the search for what is "Islam» and what is not (Islam), which action represents Islam and what does not (represents Islam). ${ }^{6}$ The aim is to provide

${ }^{3}$ Ulama, also spelled ulema, Arabic 'ulamā', the learned of Islam, those who possess the quality of 'ilm, "learning," in its widest sense. From the 'ulama', who are versed theoretically and practically in the Muslim sciences, come the religious teachers of the Islamic communitytheologians (mutakallimun), canon lawyers (muftis), judges (qadis), professors-and high state religious officials like the shaikh al-Islām. In a narrower sense, 'ulamä' may refer to a council of learned men holding government appointments in a Muslim state. Encyclopedia Britanica,

${ }^{4}$ Jajat Burhanuddin, Media dan Pergeseran Otoritas Ulama, MizanPublika, Jakarta, 2012

${ }^{5}$ Mutohharun Jinan, Jurnal Komunikasi Islam, ISBN 2088-6314, Vol. 03, 2 Desember 2013.322

${ }^{6}$ Statement calling for tolerance and unity in the Muslim world that was issued on 9 November 2004 (27th of Ramadan 1425 AH) by King Abdullah II bin Al-Hussein of Jordan. Subsequently, a three-point ruling was issued by 200 Islamic scholars from over 50 countries, focusing on issues 
clarity to the modern world of "true Islam (الطبيعة الحقيقية للإسلام)" and «true Islam" (وطبيعة الإسلام الحقيقي). To further corroborate the principle of religious authority on this statement, King Abdullah II sent the following three questions to 24 senior ulama from around the world who represented the whole The Flow and School of Islam: 1. Who is a Muslim? 2. Is it permissible to conduct Takfir (sentenced to Gentiles)? 3. Who has the right to issue a fatwa?

Based on the fatwa of the great scholars (العلماء الكبار) - including ShaykhAzhar (شيخ الأزهر), Ayatollah As-Sistaniy (آية الله السيستاري), Sheikh Qardhawiy (شيخ القرضاوي) - in July 2005, King Abdullah II held an International Islamic Conference that invited 200 world ss leading Ulama from 50 countries. In Amman, the clerics had issued a guide on three fundamental issues (which later became known as "Three Points of (Amman Message/ (محاور رسالة عمان الثلاثة) Here is an excerpt Charter Amman from International Islamic Conference held in Amman, Jordan, With the theme of «Ultimate Islam and Its Role in Modern Society» (27-29 JumadilUla 1426 H. / 4-6 July 2005) and attended by hundreds of Ulama ifrom around the world as follows: [1] Anyone who follows the school of four of AhlwalJamaah (school of Hanafiy, Malikiy, Syafiriy, Hanbali), school of Jakfariy, school of Zaydiyyah, school of Ibadiy, school of Dhahiriy, then he is a Muslim and should not be mentakfir his (convict unbelievers) And forbidden his blood, his honor and his treasure. And also in the fatwa of Fadlilatusy Shaykh Al-Azhar should not condemn the scholars of al-Ashrariyyah and the true Tashawuf sect. Likewise should not be sentenced to kafirulama who understand Salaf al-Shaleeh.

The Amman Message started as a detailed statement released the eve of the 27th of Ramadan 1425 AH / 9th November 2004 CE by H.M. King Abdullah II bin Al-Hussein in Amman, Jordan. It sought to declare what Islam is and what it is not, and what actions represent it and what actions do not. Its goal was to clarify to the modern world the true nature of Islam and the nature of true Islam. In order to give this statement more religious authority, H.M. King Abdullah II then sent the following three questions to 24 of the most senior religious scholars from all around the world representing all the branches and schools of Islam: (1) Who is a Muslim?(2) Is it permissible to declare someone an apostate (takfir)? (3) Who has the right to undertake issuing fatwas (legal rulings)?

of defining who is a Muslim, excommunication from Islam (takfir) and principles related to delivering religious edicts ( fat \wa). 
Millatī, Journal of Islamic Studies and Humanities, Vol. 3, No. 2, Des. 2018: 173-187

Based on the fatwas provided by these great scholars (who included the Shaykh Al-Azhar; Ayatollah Sistani and Sheikh Qaradawi), in July 2005 CE, H.M. King Abdullah II convened an international Islamic conference of 200 of the world's leading Islamic scholars 'Ulama) from 50 countries. In Amman, the scholars unanimously issued a ruling on three fundamental issues (which became known as the 'Three Points of the Amman Message'): They specifically recognized the validity of all 8 Mathhabs (legal schools) of Sunni, Shi'a and Ibadhi Islam; of traditional Islamic Theology (Ash'arism); of Islamic Mysticism (Sufism), and of true Salafi thought, and came to a precise definition of who is a Muslim; Based upon this definition they forbade takfir (declarations of apostasy) between Muslims; and Based upon the Mathahib they set forth the subjective and objective preconditions for the issuing of fatwas, thereby exposing ignorant and illegitimate edicts in the name of Islam.

These Three Points were then unanimously adopted by the Islamic World's political and temporal leaderships at the Organization of the Islamic Conference summit at Mecca in December 2005. And over a period of one year from July 2005 to July 2006, the Three Points were also unanimously adopted by six other international Islamic scholarly assemblies, culminating with the International Islamic Figh Academy of Jeddah, in July 2006. In total, over 500 leading Muslim scholars worldwide.

This amounts to a historical, universal and unanimous religious and political consensus (ijma') of the Ummah (nation) of Islam in our day, and a consolidation of traditional, orthodox Islam. The significance of this is: (1) that it is the first time in over a thousand years that the Ummah has formally and specifically come to such a pluralistic mutual inter-recognition; and (2) that such a recognition is religiously legally binding on Muslims since the Prophet (may peace and blessings be upon him) said: My Ummah will not agree upon an error.

This declaration is a good news not only for Muslims, for whom it provides a basis for unity and a solution to infighting, but also for non-Muslims. ${ }^{8}$ For the safeguarding of the legal methodologies of Islam (the Mathahib) necessarily means inherently preserving traditional Islam's internal 'checks and balances'. It thus assures balanced Islamic solutions for essential issues like human rights;

${ }^{7}$ See Ibn Majah, Sunan, Kitab al-Fitan, Hadith no.4085.

${ }^{8}$ As George Yeo, the Foreign Minister of Singapore, declared in the 60th Session of the U.N. General Assembly (about the Amman Message): "Without this clarification, the war against terrorism would be much harder to fight." 
women's rights; freedom of religion; legitimate jihad; good citizenship of Muslims in non-Muslim countries, and just and democratic government. It also exposes the illegitimate opinions of radical fundamentalists and terrorists from the point of view of true Islam.

Finally, whilst this by the Grace of God is a historical achievement, it will clearly remain only principial unless it is put into practice everywhere. For this reason, H.M. King Abdullah II is now seeking to implement it, God willing, through various pragmatic measures, including (1) inter-Islamic treaties; (2) national and international legislation using the Three Points of the Amman Message to define Islam and forbid takfir; (3) the use of publishing and the multi-media in all their aspects to spread the Amman Message; (4) instituting the teaching of the Amman Message in school curricula and university courses worldwide; and (5) making it part of the training of mosquelmams and making it included in their sermons.

The message of Amman not only gave birth to a joint declaration, but also wanted to create a common consensus in the Islamic world globally. A consensus that leads to religious authority is needed to create shared thinking with regard to global issues. ${ }^{9}$ As it is known, religious authority ${ }^{10}$ affects many Muslims and non-Muslims in their everyday lives as well as in exceptional circumstances. Whether derived from culturally accepted traditions, from legal and bureaucratic norms, from charismatic or successful individuals, or from unique personal or communal experiences religious authority has an enormous impact on the behavior of Muslims everywhere. ${ }^{11}$

${ }^{9}$ Recently, we seem to be under the perception of a growing fragmentation and decentralization of religious authority in the Muslim world. No particular locale or community appear to be unaffected by the phenomenon. Internet sites, videos, "social" media, TV programs, ad-hoc establishments, itinerant carriers of religious messages, everyone and anyone now seems to be able to cast himself or herself as an authority-wielding Muslim. While increasing decentralization has been always a component of any religion, developments in the recent couple of centuries may have hastened the process considerably.

${ }^{10}$ The recognized capacity of an individual or an institution to sanction the undertaking of religious acts, both private and public, Kholis Rido, Memperbincangkan Otoritas Keagamaan dalam Islam, Jurnal Dialog, ISSN: 0126-396X, No. 65 Tahun XXXI, juli 2008, 52-53

${ }^{11}$ Khaled Abou El-Fadl, And God Knows the Soldier: The Authoritative and Authoritarian in Islamic Discourse, Oxford, Oneworld Publication, 2002, 14 
Millatī, Journal of Islamic Studies and Humanities, Vol. 3, No. 2, Des. 2018: 173-187

\section{Designing Plurality Through Risalat Amman}

The main sources of this paper are some articles from the book Pluralism in Democratic Societies: Challenges and Prospects for Southeast Asia, Europe, and the United States in the New Millennium, edited by K.S. Nathan, Singapore: Konrad-Adenauer-Stiftung (KAS), 2010, andarticle "Is Atheism, like Communism, Illegal in Indonesia?" Written by Salim Osman in Jakarta Post, Friday, February 10, 2012.

There are two articles from the book Pluralism in Democratic Societies: Challenges and Prospects for Southeast Asia, Europe, and the United States in the New Millennium, Azyumardi Azra's article on "The Impact of Democracy on Conflict Resolution "and a written, Leonard Swidler on" Freedon of Religion and Dialogue: Moving Globalization from 'Destruction' to 'Construction.'

Leonard Swidler describes an interesting chronology in the development of religious freedom and dialogue. ${ }^{12}$ According to him, full religious freedom did not exist until the end of the 18th century and authentic dialogue only occurred in the 20th century. ${ }^{13}$ It happens because of various things. For example, although the first centuries of Christian thinkers tended to affirm religious freedom, it soon changed when Constantine the Great made Christianity an imperial religion. Historically, religious freedom has only been regarded as a human right by the events of the French Revolution (Declaration des droits des hommes et citoyens) and the establishment of the United States of America (Bill of Rights).

In today's world, religious freedom and dialogue arise because of a new awareness. In the fact of interdependence between humans, there is a need to learn from other religions, be open to other religions, and be ready to find new truths of that relationship together.

In the Indonesian context Azyumardi Azra explained an interesting thought. ${ }^{14}$ From an Islamic point of view, Azra explained that Indonesia is the country with the largest Muslim population in the world but also lives side by

${ }^{12}$ See Leonard Swidler, "Freedom of Religion and Dialogue: Moving Globalization from 'Destruction' to 'Construction',' in Religious Pluralism in Democratic Societies: Challenges and Prospect for Southeast Asia, Europe, and the United States in the New Millenium, edited by K.S. Nathan,Singapore: Konrad-Adenauer-Stiftung (KAS), 2010, p.13-33.

${ }^{13}$ Swidler, Freedom of Religion and Dialogue, p. 13.

${ }^{14}$ See Azyumardi Azra, "An Islamic Perspective of Religious Pluralism in Indonesia: The Impact of Democracy on Conflict Resolution," in Religious Pluralism in Democratic Societies: Challenges and Prospect for Southeast Asia, Europe, and the United States in the New Millenium, edited by K.S. Nathan, Singapore: Konrad-Adenauer-Stiftung (KAS), 2010, p. 225-240. 
side with religious followers such as Protestant, Catholic, Hindu, Buddhist and Confucian. According to some estimates, the total population of Indonesia is 206 million people, with $87.21 \%$ Muslims, $6.04 \%$ of Protestants, 3.58\% Catholics, $1.83 \%$ of Hindus, and $0,31 \%$ of people from other religions and faith groups. ${ }^{15}$

In the article shown that religious religious facts demand an attitude of openness to learn from and with other religions. The demand is directly related to the concept of social solidarity. The tension between exclusivity and inclusiveness determines which attitudes are shown to the fact of religious plurality.

Through Amman Message, it was agreed that whosoever is an adherent to one of the four Sunni schools (Mathahib) of Islamic jurisprudence (Hanafi, Maliki, Shafi'i and Hanbali), the two Shi'i schools of Islamic jurisprudence (Jafari and Zaydi), the Ibadi school of Islamic jurisprudence and the Thahiri school of Islamic jurisprudence, is a Muslim. Declaring that person an apostate is impossible and impermissible. Verily his (or her) blood, honour, and property are inviolable. Moreover, it is not possible nor permissible to declare whosoever subscribes to the Ash'ari creed or whoever practices real Tasawwuf (Sufism) an apostate. Likewise, it is not possible nor permissible to declare whosoever subscribes to true Salafi thought an apostate. Equally, it is not possible nor permissible to declare as apostates any group of Muslims who believes in God, Glorified and Exalted be He, and His Messenger (may peace and blessings be upon him) and the pillars of faith, and acknowledges the five pillars of Islam, and does not deny any necessarily self-evident tenet of religion.

There exists more in common between the various schools of Islamic jurisprudence than there is difference between them. The adherents to the eight schools of Islamic jurisprudence are in agreement as regards the basic principles of Islam. All believe in Allah (God), Glorified and Exalted be He, the One and the Unique; that the Noble Qur'an is the Revealed Word of God; and that our master Muhammad, is a Prophet and Messenger unto all mankind. All are in agreement about the five pillars of Islam: the two testaments of faith (shahadatayn); the ritual prayer (salat); alms-giving (zakat); fasting the month of Ramadan (sawm), and the Hajj to the sacred house of God (in Mecca). All are also in agreement about the foundations of belief: belief in Allah (God), His angels, His scriptures, His messengers, and in the Day of Judgment, in Divine Providence in good and in evil. Disagreements between the 'ulama (scholars) of the eight schools of Islamic

${ }^{15}$ Azra, An Islamic Perspective...., p. 228. 
Millatī, Journal of Islamic Studies and Humanities, Vol. 3, No. 2, Des. 2018: 173-187

jurisprudence are only with respect to the ancillary branches of religion (furrf) and not as regards the principles and fundamentals (usul) [of the religion of Islam]. Disagreement with respect to the ancillary branches of religion (furrf) is a mercy. Long ago it was said that variance in opinion among the 'ulama' (scholars) 'is a good affair'. ${ }^{16}$

Acknowledgement of the schools of Islamic jurisprudence (Mathahib) within Islam means adhering to a fundamental methodology in the issuance of fatwas: no one may issue a fatwa without the requisite personal qualifications which each school of Islamic jurisprudence determines [for its own adherents]. No one may issue a fatwa without adhering to the methodology of the schools of Islamic jurisprudence. No one may claim to do absolute Ijtihad and create a new school of Islamic jurisprudence or to issue unacceptable fatwas that take Muslims out of the principles and certainties of the Shari'ah and what has been established in respect of its schools of jurisprudence. ${ }^{17}$

The essence of the Amman Message, which was issued on the Blessed Night of Power in the year $1425 \mathrm{H}$ and which was read aloud in the Masjid AlHashimiyyin, is adherence to the schools of Islamic jurisprudence and to their fundamental methodology. Acknowledging the schools of Islamic jurisprudence and affirming discussion and engagement between them ensures fairness, moderation, mutual forgiveness, compassion, and engaging in dialogue with others.

Amman calls for casting aside disagreement between Muslims and unifying their words and stances; reaffirming their mutual respect for each other; fortifying mutual affinity among their peoples and states; strengthening the ties of brotherhood which unite them in the mutual love of Allah. And we call upon Muslims to not permit discord and outside interference between them.

Allah, Glorified be He, says:

The believers are naught else than brothers. Therefore makepeace between your brethren and observe your duty to Allah that perhaps ye may obtain mercy. (Al-Hujurat, 49:10).

Allah through his revelations has given clear clues as to how a servant should interact with his neighbor. Similarly, this has been exemplified by his messenger Muhammad. And the above Risalat Aman is considered sufficient to describe how exactly Islam according to its people to address the problem of

\footnotetext{
${ }^{16}$ See Amman Message on http://ammanmessage.com/the-amman-message-full/

${ }^{17}$ See also Amman Message on http://ammanmessage.com/final-conference-statement/
} 
plurality. The sermon stressed the need to re-emphasise Islam's core values of compassion, mutual respect, tolerance, acceptance and freedom of religion". Amman underline the need to strengthen dialogue among Islamic schools of jurisprudence, affirm the true faith of their followers and the inadmissibility of accusing them of apostasy (takfir), as well as the inviolability of their blood, honour and property, as long as they believe in Allah the Mighty and Sublime, in the Prophet pbuh and in the other pillars of the Islamic faith, respect the pillars of Islam and do not deny any self-evident tenet of religion.

Then Amman also appealed condemn the audacity of those who are not qualified in issuing religious rulings (fatwa), thereby flouting the tenets and pillars of the religion and the well-established schools of jurisprudence. Consequently, compliance with the methodology of fatwa, as approved by scholars, must be observed in accordance with the relevant provisions of the International Islamic Conference held in Amman in July 2005 and with the recommendations of the Preparatory Forum of Muslim Scholars and Intellectuals prior to the Summit convened by the Custodian of the Two Holy Mosques in Honoured Mecca from 9 to 11 September $2005 .^{18}$

\section{Risalat Amman as Nusantara Ulama Reference}

In Indonesia, Ulama as an institution has a tendency to be grouped into several organizations. For example NU and Muhammadiyah. In terms of general ideology and way of thinking. In terms of geographic scale, there is SilahUlama Forum al-rahim West Java. Another type of Ulema 'is the MUI (Indonesian Council of Ulama') which evolved from national organizations to local scales. Despite organizational diversity, Ulama 'have the same role, ie spreading Islam.

All in all, relations among the majority of the Islamist movements and groups active within the Indonesian socio-religious scene have been marked by continuous intellectual disagreements, social struggles and fierce competition. They are all constantly vying for the support and loyalties of the "religious" popular base; and, this competition has been played out with each group trying to prove that it is the onlymovement amongst all the groups and movements, which has full rights and authority in representing the "true and pure understanding of Islam". Indeed, the issues and areas of disagreement between the movements and groups range from religious and jurisprudential issues to political, social

\footnotetext{
${ }^{18}$ See Amman Message on http://ammanmessage.com/the-amman-message-full/
} 
Millatī, Journal of Islamic Studies and Humanities, Vol. 3, No. 2, Des. 2018: 173-187

and ideological issues, and quite often, many of these conflicting opinions and disagreements lead to mutual hostility, open enmity and even reciprocated acts of takfir. This general atmosphere of animosity continues despite the fact that the majority of these movements and groups have common and shared long-term objectives, such as the Islamization of society and

Establishing the "Islamic state" governed by Islamic Sharia From its inception, Indonesia has been characterized as a civil and not religion state but religious state. ${ }^{19}$ Religion, here, is meant in the Western Medieval European sense, means that this does not negate that the ruling regime has an overall conservative character that, to a great degree, reflects the royal family's heritage and the continuation of a historical legacy. Indeed, it is this heritage and the longevity of this historical legacy carried by the royal family that has helped secure its sense of symbolic legitimacy. The state was not established on one religion foundation and its legitimacy has not been built around any revolutionary or sectarian "religious ideology". Nor does it allege to aim to establish an Islamic state in the style of the Islamist movements.

From the outset, the country's founder, Muhammad Hatta was very keen to ensure that the state would have a civil political character. He was clear to reinforce this message on August 17, 1945, during a ceremony in which the country's independence was declared, when he said, "On thisspecial occasion, I declare that the fundamental law for this area will be created, and the electoral law amended in a manner appropriate to the spirit of the country, its place, its people and its environment" 20 . The articles of the Indonesian constitution do not allow for any ambiguity or grey areas in which a religious character to the state could be construed at the expense of the civil political system. At the same time, there are no hostile postures taken towards Islam and Islamic law (Sharia) anywhere in the constitution. ${ }^{21}$

The response of Indonesian Ulama by holding this Seminar is conducted by Institute of Religion and Cultural Studies of Indonesia (LSABI), took place on Saturday, May 19, 2012 and held at Hotel Bumi Wiyata Depok West Java. In this seminar, we discussed the idea of formulation such as the resolution related to the unity and harmony of Muslims in Indonesia, as a follow up of

${ }^{19}$ See Sri Edi-Swasono, Bung Hatta: Bapak Kedaulatan Rakyat, (Jakarta: Pustaka Hatta), 2002, 164

${ }^{20}$ Nurcholis Madjid, Bung Hatta: dari Demokrasi Minangkabau ke Demokrasi Indonesia, Jurnal Reformasi Ekonomi, Vol. III, No. 1, Januari-Juni 2001, 80

${ }^{21}$ Wahid, Abdurrahman, 1989, "Kata Pengantar” dalam Einar Martahan Sitompul NU dan Pancasila, Jakarta: Sinar Harapan, vii 
the discussion results from the previous sessions. In the end, the participants took turns in acclamation with a declaration called Risalah Depok, inspired by Amman's Message as an international Islamic conference calling on the theme of 'Ultimate Islam and Its Role in Modern Society' July 4-6, 2005 in Amman, attended by hundreds of Islamic leaders from dozens of Muslim countries.

\section{Conclusion}

Taking note of the above, we can demand a neutral role for the state in the relations of its citizens. Such roles are usually articulated in the idea of separation of religion and state. The idea of separation of religion and state had indeed been initiated by Pope Gregory VII (1021-1084) who separated Catholicism from the Roman Empire. ${ }^{22}$ However, the effort did not show significant results. Such an idea was subsequently echoed in the French revolution, and the American Constitution. ${ }^{23}$

Admittedly, the difference is real. However, it should not be a difference, but a common ground. All that can only be done when there is room for acceptance of difference and acknowledge and appreciate the difference. Cak Nur said, "optimism against the reality of that difference is called PLURALISM".

Democracy and civil religion, are two things that must be developed. How to do the dialogue, to awaken maturity in religion. Gus Dur said, "religion does not need to be defended", which needs to be defended is the community. If in the name of religion and then oppress the community, then surely he is not a religion. Religion is present precisely to defend society, to defend the oppressed. Religion serves to improve the order of life to be cultured and civilized.

22 Swidler, Freedom of Religion and Dialogue, p.16.

${ }^{23}$ K.S. Nathan, "CONCLUSION: Globalization and the Post-9/11 Era: Problems and Prospects for Multi-Religious Coexistence and Cooperation in Southeast Asia, Europe, and America," in Religious Pluralism in Democratic Societies: Challenges and Prospect for Southeast Asia, Europe, and the United States in the New Millenium, edited by K.S. Nathan,Singapore: Religious Pluralism in Democratic Societies: Challenges and Prospect for Southeast Asia, Europe, and the United States in the New Millenium Konrad-Adenauer-Stiftung (KAS), 2010, p. 285 
Millatī, Journal of Islamic Studies and Humanities, Vol. 3, No. 2, Des. 2018: 173-187

\section{References}

Abduh, Muhammad, Risalat al-Tauhid, Egypt: Majlis al-'Ala li Shu'un Islamiyah, 2009

Abou El-Fadl, Khaled, And God Knows the Soldier: The Authoritative and Authoritarian in Islamic Discourse, Oxford, Oneworld Publication, 2002

Arsalan, Amir Syakib, Limaza Ta'akhara Muslimun wa Taqaddama Ghairuhum, Lebanon: Dar Maktabah al-Hayat, 2011

Burhanuddin, Jajat, Media dan Pergeseran Otoritas Ulama, MizanPublika, Jakarta, 2012

Edi-Swasono, Sri, Bung Hatta: Bapak Kedaulatan Rakyat, (Jakarta: Pustaka Hatta), 2002

Jinan, Mutohharun, Jurnal Komunikasi Islam, ISBN 2088-6314, Vol. 03, 2 Desember 2013.322

Majah, Ibn, Sunan, Kitab al-Fitan, Hadith no.4085.

Message, Amman on http://ammanmessage.com/the-amman-message-full/

Message, Amman on http://ammanmessage.com/final-conference-statement/

Madjid, Nurcholis, Bung Hatta: dari Demokrasi Minangkabau ke Demokrasi Indonesia, Jurnal Reformasi Ekonomi, Vol. III, No. 1, Januari-Juni 2001

Rido, Kholis, Memperbincangkan Otoritas Keagamaan dalam Islam, Jurnal Dialog, ISSN: 0126-396X, No. 65 Tahun XXXI, juli 2008

Wahid, Abdurrahman, 1989, "Kata Pengantar" dalam Einar Martahan Sitompul NU dan Pancasila, Jakarta: Sinar Harapan

Azra, Azyumardi. "An Islamic Perspective of Religious Pluralism in Indonesia: The Impact of Democracy on Conflict Resolution," in Religious Pluralism in Democratic Societies: Challenges and Prospect for Southeast Asia, Europe, and the United States in the New Millenium, edited by K.S. Nathan, Singapore: Konrad-Adenauer- Stiftung (KAS), 2010

Cuff, E.C., W.W. Sharrock, and D.W. Francis.Perspectives in Sosiology, Fourth Edition. London: Routledge, 1998

Nathan, K.S., "INTRODUCTION: Religious Pluralism in Southeast Asia, Europe, and the United States: The Foundationsof Coexistence" in Religious Pluralism in Democratic Societies: Challenges and Prospect for Southeast Asia, Europe, and the United States in the New Millenium, edited by K.S. Nathan, Singapore: Konrad-Adenauer- Stiftung (KAS), 2010 
. "CONCLUSION: Globalization and the Post-9/11 Era: Problems and Prospects for Multi-Religious Coexistence and Cooperation in Southeast Asia, Europe, and America," in Religious Pluralism in Democratic Societies: Challenges and Prospect for Southeast Asia, Europe, and the United States in the New Millenium, edited by K.S. Nathan,Singapore: Religious Pluralism in Democratic Societies: Challenges and Prospect for Southeast Asia, Europe, and the United States in the New Millenium Konrad-Adenauer-Stiftung (KAS), 2010

Osman, Salim, "Is Atheism, like Communism, Illegal in Indonesia?" in Jakarta Post, Friday, February 10, 2012 (no page)

Seda, Francisia SSE. Menuju Gereja yang Makin Mengindonesia: Suatu Perspektif Sosiologis. Diktat kuliah Sosiologi Agama, 2012

Swidler, Leonard. "Freedom of Religion and Dialogue: Moving Globalization from 'Destruction' to 'Construction'," in Religious Pluralism in Democratic Societies: Challenges and Prospect for Southeast Asia, Europe, and the United States in the New Millenium, edited by K.S. Nathan,Singapore: Konrad-Adenauer-Stiftung (KAS), 2010 
